Sumarsih ${ }^{1}$

Nurmalina $^{2}$

Astuti $^{3}$

\title{
Meningkatkan Kemampuan Kognitif dalam Mengenal Warna dengan Metode Eksperimen
}

\begin{abstract}
Abstrak
Penelitian ini bertujuan untuk meningkatkan kemampuan kognitif dalam mengenal warna melalui metode eksperimen pada anak usia 3-4 tahun di KB Pertiwi. Jenis penelitian yang digunakan adalah Penelitian Tindakan Kelas yang dilakukan secara kolaboratif antara peneliti dengan guru kelas. Penelitian ini terdiri dari dua siklus dan setiap siklusnya dilaksanakan 3 kali pertemuan. Subjek penelitian ini adalah 15 anak di KB Pertiwi yang terdiri dari 7 anak laki-laki dan 8 anak perempuan. Objek penelitian adalah kemampuan kognitif dalam mengenal warna. Teknik pengumpulan data melalui observasi dan dokumentasi. Instrument yang digunakan adalah lembar observasi (check list) dan dokumentasi. Teknik analisis data dilakukan secara deskriptif kuantitatif. Hasil penelitian menunjukkan bahwa terdapat peningkatan kemampuan kognitif dalam mengenal warna. Hasil observasi pada pra tindakan menunjukkan bahwa anak yang berkriteria berkembang sesuai harapan ada 2 orang atau 13\%. Pada siklus 1 meningkat menjadi 4 orang atau 27\% dan siklus 2 meningkat lagi menjadi 10 anak atau 66,7\%. Dengan demikian, dapat disimpulkan bahwa melalui metode eksperimen dapat meningkatkan kemampuan kognitif dalam mengenal warna pada anak usia 3-4 tahun di KB Pertiwi.
\end{abstract}

\section{Kata Kunci: Kemampuan Kognitif, Mengenal Warna, Metode Eksperimen}

\begin{abstract}
The study aims to improve toddler's cognitive ability in understanding colors by applying an experimental method at KB Pertiwi. This is classroom action research, which is conducted collaboratively between researcher and classroom teacher. This study has of two cycles and each cycle was held in three meetings. The subject of the study were 15 children in KB Pertiwi consisted of 7 boys and 8 girls. The object of the study is cognitive ability in recognizing color. The data collection techniques used are observation and documentation. Are the instrument used in the study list (check list) and documentation. Data analysis techniques carried out in a quantitative descriptive manner. The findings of the study are showed that there is an improvement on toddler's cognitive ability in understanding color. The findings of the observation in the pre-action showed there were 2 achieved the unitesion children or $13 \%$. In cycle 1 it increased to 4 children or $27 \%$ and cycle 2 increased again to 10 children or $66,7 \%$. Thus, it can be concluded that through experimental methods can improve cognitive ability in recognizing color in children aged 3-4 years in KB Pertiwi.
\end{abstract}

Keywords: cognitive abilities, recognize color, experimental method

\footnotetext{
${ }^{1}$ Prodi PG-PAUD Universitas Pahlawan Tuanku Tambusai, Riau, Indonesia

Email : sumarsih.up@gmail.com

${ }^{2}$ Prodi PG-PAUD Universitas Pahlawan Tuanku Tambusai, Riau, Indonesia

${ }^{3}$ Prodi Pendidikan Matematika Universitas Pahlawan Tuanku Tambusai, Riau, Indonesia
}

Aulad : Journal on Early Childhood, 2018, 1(1), $72-77$ 


\section{PENDAHULUAN}

Kelompok bermain juga dapat didefinisikan sebagai salah satu bentuk layanan pendidikan bagi anak usia tiga sampai enam tahun yang berfungsi untuk meletakkan dasar-dasar kearah perkembangan, sikap, dan pengetahuan dan keterampilan yang diperlukan bagi anak usia dini dalam menyesuaikan diri dengan lingkungannya dan untuk pertumbuhan serta perkembangan selanjutnya, sehingga siap memasuki pendidikan dasar.

Dapat disimpulkan bahwa setiap program kegiatan belajar di kelompok bermain harus mencakup fungsi yang bermanfaat dalam mengembangkan seluruh kemampuan yang dimiliki anak sesuai dengan tahapan perkembangan masing-masing anak. Dalam kegiatan di kelompok bermain, anak dapat mengenal dunia sekitar, melatih anak untuk bersosialisasi, mengenalkan anak dengan peraturan-peraturan dan penanaman nilai kedisiplinan pada anak tanpa meninggalkan masa-masa bermainnya. Pembinaan dalam pendidikan anak usia dini dilakukan untuk membantu pertumbuhan dan perkembangan jasmani dan rohani agar memiliki kesiapan dalam menghadapi tugas perkembangan selanjutnya.

Adapun aspek perkembangan ada lima yaitu aspek fisik motorik, intelektual, sosial, emosional, dan bahasa. Kelima aspek itu berkembang pesat pada usia dini, hal ini memerlukan perhatian khusus supaya anak dapat optimal dalam perkembangannya. Keberhasilan akan pertumbuhan dan perkembangan pada masa usia dini sangat berpengaruh pada keberhasilan masa-masa setelahnya.Untuk itu, pendidikan anak usia dini memegang peranan penting dalam pertumbuhan dan perkembangan.

Salah satu aspek penting yang perlu dikembangkan dalam pembelajaran pada anak usia dini adalah aspek intelektual/kognitif. Aspek perkembangan kognitif dalam pendidikan anak usia dini sering disebut pula daya pikir. Perkembangan kognitif pada anak sangat diperlukan guna untuk mengembangkan pengetahuannya tentang apa yang mereka lihat, dengar, rasa, cium, dan raba melalui panca indra yang dimiliki anak. Tujuan dari pengenalan warna yaitu sebagai dasar bagi pengetahuan anak mengenai pengetahuan selanjutnya yang akan menjadi bekal pengetahuan bagi anak. Hal ini sesuai dengan pendapat Piaget tentang tahapan perkembangan kognitif. Piaget menyatakan bahwa anak usia 3-4 tahun berada pada tahap praoperasional yang mulai mengenal beberapa simbol dan meningkat pada tahap selanjutnya yaitu mampu memecahkan persoalan sederhana secara konkrit. Mengenal simbol warna akan memberikan bekal kepada anak untuk pemecahan persoalan sederhana yang berhubungan dengan warna. Oleh sebab itu, pembelajaran dalam pengenalan warna menjadi hal yang penting bagi anak dan pembelajarannya disesuaikan dengan tahap dan karakteristik belajar anak.

Karakterisik belajar bagi anak usia dini yaitu belajar yang melibatkan anak secara langsung dan belajar sambil bermain. Namun, pada kenyataannya teori belajar yang digunakan oleh guru pada umumnya adalah teori behavioristik. Menurut teori behavioristik, belajar perubahan tingkah laku sebagai akibat dari adanya interaksi antara stimulus dan respon. Dengan kata lain, belajar merupakan bentuk perubahan yang dialami siswa dalam hal kemampuannya untuk bertingkah laku dengan cara yang baru sebagai hasil interaksi antara stimulus dan respon. Seorang dianggap telah belajar sesuatu jika ia dapat menunjukkan perubahan tingkah lakunya. Menurut teori ini yang terpenting adalah input yang berupa stimulus dan output yang berupa respons sedangkan apa yang terjadi diantara stimulus dan respon dianggap tidak penting diperhatikan karena tidak dapat diamati dan tidak dapat diukur.

Berdasarkan dari hasil pengamatan di KB Pertiwi yang terletak di Desa Hangtuah Kecamatan Perhentian Raja menunjukkan bahwa kemampuan kognitif anak dalam mengenal warna belum sesuai dengan pencapaian perkembangan anak usia 3-4 tahun. Hal ini dibuktikan dari pengamatan penulis pada tanggal 12 Februari tahun 2018, dari 15

Aulad : Journal on Early Childhood, 2018, 1(1), $72-77$ 
anak di kelas hanya terdapat 2 anak yang mencapai kemampuan mengenal warna yang sesuai dengan tingkat pencapaian perkembangan anak usia 3-4 tahun yang terdapat pada Permendiknas Tahun 2009. Hal ini disebabkan proses dalam mengenal warna kurang bermakna bagi anak. Proses pengenalan warna dilakukan oleh guru lebih cenderung memberikan nama-nama warna dan menunjukkan warna dengan metode ceramah. Dengan kurangnya variasi metode pembelajaran dalam kegiatan pembelajaran mengakibatkan perkembangan kognitif anak kurang terlatih, anak hanya menerima informasi dan kurangnya pemberian kesempatan kepada anak untuk memiliki pengalaman langsung melakukan percobaan sederhana.

Dalam hasil observasi yang dilakukan peneliti, peneliti memilih pengenalan warna sebagai sarana yang tepat untuk mengembangkan kemampuan kognitif anak di KB Pertiwi. Selain itu, pemilihan strategi, pendekatan, dan metode belajar yang tepat juga mendukung keberhasilan pembelajaran. Salah satu metode pembelajaran pada anak usia dini yaitu pembelajaran dengan metode eksperimen atau percobaan sederhana. Pembelajaran yang berorientasi pada perkembangan yang lebih banyak memberikan kesempatan kepada anak untuk menemukan sesuatu yang baru dengan cara-cara yang menarik bagi mereka. Dalam pembelajaran yang melakukan kegiatan percobaan akan mengembangkan potensi dan kreativitas anak.

Metode eksperimen adalah pemberian kesempatan kepada anak didik atau kelompok, untuk dilatih melakukan suatu proses atau percobaan (Djamarah, 2005:234). Penggunaan metode ini mempunyai tujuan agar anak mampu mencari dan menemukan sendiri berbagai jawaban atau persoalan-persoalan yang dihadapinya dengan mengadakan percobaan sendiri secara sederhana. Kelebihan dari metode ini adalah anak lebih percaya pada kesimpulan berdasarkan pada percobaan yang dilakukannya sendiri.

\section{METODE PENELITIAN}

Metode penelitian yang digunakan oleh penulis dalam penelitian ini adalah metode penelitian tindakan kelas (PTK) yang bersifat kolaboratif dan partisipasif dengan melibatkan mahasiswa sebagai peneliti dan guru kelas KB Pertiwi sebagai kolaborator sekaligus pengajar. Penelitian ini bertujuan untuk meningkatkan kemampuan dalam perkembangan kognitif dengan mengenal warna melalui metode eksperimen pada siswa usia 3-4 tahun di KB Pertiwi di Desa Hangtuah Kecamatan Perhentian Raja Kabupaten Kampar.

Dalam penelitian ini menggunakan bagan alur penelitian Arikunto. S, dkk (2016:42). Penelitian ini direncanakan akan dilaksanakan dalam dua siklus yaitu siklus I dan siklus II. Dimana dalam satu siklus terdiri dari empat tahapan yaitu perencanaan (planning), tindakan (acting), pengamatan (observasi) dan refleksi (reflecting) dan seterusnya. Dalam penelitian ini aspek yang dikembangkan adalah kemampuan kognitif dalam mengenal warna melalui metode eksperimen. Salah satu cara mengatasi permasalahan tersebut adalah dengan menyusun perencanaan belajar mengajar yang baik. Untuk memecahkan masalah, peneliti membuat rencana baru yang mendorong tercapainya tujuan yang diharapkan.

\section{HASIL DAN PEMBAHASAN}

Penyebab rendahnya kemampuan anak mengenal warna di KB Pertiwi yaitu, penggunaan metode pembelajaran yang kurang menarik minat anak yaitu metode ceramah. Dalam metode ceramah anak cenderung merasa bosan karena hanya mendengarkan guru menjelaskan tanpa mereka melakukan sendiri kegiatan yang berhubungan dengan warna.

Aulad : Journal on Early Childhood, 2018, 1(1), $72-77$ 
Berdasarkan hasil penelitian yang telah dilakukan dapat diketahui anak yang belum berkembang pada pra tindakan 9 orang anak (60\%) sedangkan pada siklus 1 tidak ada. Dengan terjadinya penurunan dari persentase tersebut disebabkan karena anak telah mampu mengenal warna meskipun dibimbing oleh guru.

Penilaian anak dan dalam kategori mulai berkembang pada pra tindakan berjumlah 4 orang anak atau $27 \%$ sedangkan pada siklus 1 yaitu 11 orang anak, hal ini disebabkan karena anak telah bersemangat dalam mengenal warna meskipun masih diingatkan oleh guru.

Penilaian anak dalam kategori berkembang sesuai harapan pada pra tindakan berjumlah 2 orang anak atau 13\% Dan pada siklus 1 berjumlah 4 orang anak atau $27 \%$. Terjadinya penaikan ini disebabkan oleh karena anak telah mampu melakukan kegiatan atau sains sederhana dan mampu mengenal warna tanpa harus diingatkan oleh guru. sedangkan penilaian anak berkembang sangat baik pada pra tindakan maupun pada siklus 1 tidak ada.

Hasil penelitian pada siklus 1 , siklus 2 menunjukkan bahwa adanya peningkatan kemampuan mengenal warna pada anak KB Pertiwi Desa Hangtuah. Berdasarkan hasil penelitian yang dilakukan pada siklus 1 penilaian anak dalam kategori belum berkembang tidak ada. Pada siklus 2 kategori belum berkembang juga tidak ada hal ini disebabkan oleh karena anak telah mampu mengenal warna.

Penilaian anak dalam kategori mulai berkembang pada siklus 1 adalah sebanyak 11 orang anak atau 73\%. Dan pada siklus 2 jumlah anak dalam kategori mulai berkembang menurun menjadi 1 orang anak atau 6,7\%. Hal ini disebabkan oleh perkembangan anak dalam mengenal warna sudah lebih baik.

Penilaian anak dalam kategori berkembang sesuai harapan pada siklus 1 berjumlah 4 orang anak atau $27 \%$ dari jumlah siswa keseluruhan. Pada siklus 2 kategori penilaian berkembang sesuai harapan dalam mengenal warna berjumlah 10 orang anak atau $66,7 \%$. Penilaian ini diperoleh berdasarkan hasil observasi pada siklus 2 yang menunjukkan peningkatan perkembangan anak dalam mengenal warna semakin baik.

Penilaian anak dalam kategori berkembang sangat baik pada siklus 1 tidak ada, namun pada siklus 2 mengalami peningkatan menjadi 4 orang anak atau (27\%). Hal ini disebabkan karena anak mampu mengenal dan mendeskripsikan warna-warna yang telah dikenalkan kepada anak selama pembelajaran sains sederhana berlangsung, bahkan ada sebagian anak yang mampu membantu temannya untuk melakukan sains warna tersebut.

Berikut persentase kemampuan mengenal warna melalui sains sederhana mulai tahap pra tindakan sampai siklus 2, dapat dilihat pada grafik berikut:

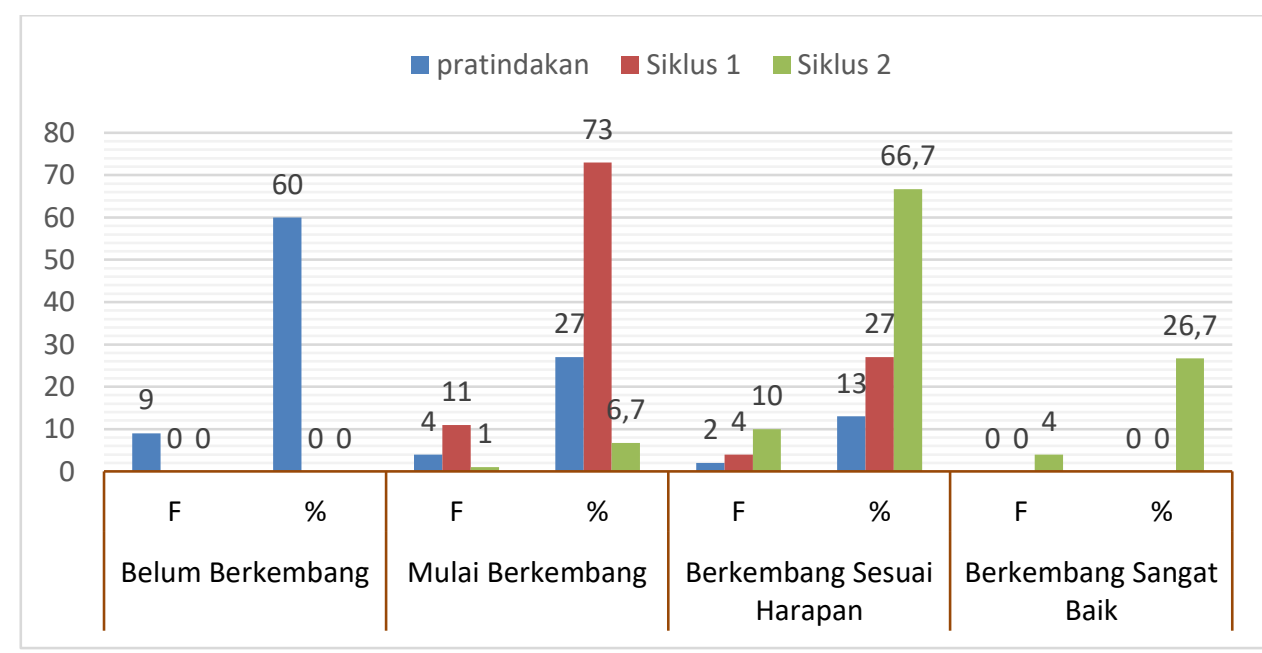

Grafik Persentase Perbandingan Pra Tindakan, Siklus 1 dan Siklus 2

Aulad : Journal on Early Childhood, 2018, 1(1), 72 - 77 
Setelah melihat hasil data kemampuan anak KB Pertiwi Desa Hangtuah dalam mengenal warna pada grafik di atas dapat diketahui bahwa bermain eksperimen sederhana dapat meningkatkan kemampuan mengenal warna. Hal ini dapat dilihat dari meningkatnya grafik persentase kemampuan mengenal warna pada anak usia 3-4 tahun setelah melakukan kegiatan eksperimen sederhana.

Hasil observasi dan penelitian pada siklus 1 terlihat anak sudah lebih menyukai kegiatan pembelajaran dan mengikutinya dengan antusias yang lebih tinggi. Kegiatan pembelajaran yang digunakan adalah dengan metode eksperimen sederhana yang tentunya aman bagi anak. Metode pembelajaran ini sangat mudah dilakukan oleh anak usia 3-4 tahun, dan kegiatan eksperimen ini sangat menyenangkan. Pada prinsipnya pembelajaran di PAUD tidak terlepas dari kegiatan bermain menyenangkan. Hal tersebut sesuai pendapat Slamet Suyanto dalam Lestari, D (2014:78) bahwa pembelajaran di PAUD harus menerapkan esensi bermain yang meliputi perasaan menyenangkan, merdeka, bebas memilih, dan membuat anak untuk terlibat aktif dalam mengikuti kegiatan itu. pada prinsipnya pembelajaran di PAUD tidak terlepas dari kegiatan bermain yang menyenangkan. Namun, dalam pelaksanaan tindakan siklus 1 suasana kelas masih kurang kondusif, hal ini disebabkan anak kurang bersemangat dalam pebelajaran.

Pada siklus 2, anak menjadi semakin antusias dan teribat aktiv dalam mengenal warna memalui metode eksperimen sederhana, serta suasana kelas sudah semakin kondusif. Hal itu dikarenakan kegiatan eksperimen warna dilakukan dengan pemberian reward kepada anak yang mau melakukan. Dengan melakukan permainan eksperimen ini anak semakin bersemangat untuk belajar, karena pada dasarnya anak sangat menyukai praktek dari pada teori.

Kemampuan mengenal warna pada anak usia 3-4 tahun pada KB Pertiwi di Desa Hangtuah Kecamatan Perhentian Raja sudah meningkat. Adapun indikator yang peneliti nilai yaitu : dapat memahami konsep makna yang berlawanan seperti kosong-penuh (dalam mengisi air warnake dalam gelas plastik), anak mampu memadankan warna dengan objek yang nyata, anak mampu mengelompokkan benda berdasarkan warna, anak dapat memasangkan benda berdasarkan warna, anak mampu memahami sebab -akibat apabila warna dicampur, dapat merangkai kegiatan sehari-hari terkait dengan pembelajaran eksperimen warna, menceritakan kembali kegiatan eksperimen warna yang telah dilakukan, mengenali warna benda-benda yang sering dilihat, mengenali dan menyebutkan warna, dapat menumpuk balok atau gelang-gelang sesuai dengan warna secara berurutan. Indikator ini berdasarkan pendapat dari Yuliani N.S (2011:158) tentang kemampuan kognitif pada anak usia 3-4 tahun.

\section{SIMPULAN DAN SARAN}

Berdasarkan hasil penelitian dan pembahasan, maka dapat disimpulkan bahwa kemampuan kognitif dalam mengenal warna pada anak usia 3-4 tahun di KB Pertiwi Desa Hangtuah, pada semester genap tahun pelajaran 2017-2018, dapat ditingkatkan melalui metode eksperimen sederhana. Metode pembelajaran ini dilakukan dengan tiga kegiatan eksperimen warna. Peningkatan kemampuan kognitif dalam mengenal warna dapat dilihat dari adanya peningkatan persentase dari tahap pra tindakan dan setelah dilakukan tindakan kelas. Penulis berharap dengan adanya penelitian inim dapat menjadi acuan dan pandangan bagi para pembacanya, baik bagi para guru, kepala sekolah, dan peserta didiknya. 


\section{DAFTAR PUSTAKA}

Arikunto, Suharsimi, dkk. (2016). Penelitian Tindakan Kelas. Jakarta: PT Bumi Aksara Djamarah. (2005). Guru dan Anak Didik Dalam Interaksi edukatif. Jakarta: PT Asdi Mahasatya

Faiqoh,E. (2011). Pengertian Kemampuan. Diakses dari [http://emprints.uny.ac.id/9227/5/bab\%202.pdf ]

Gunarti,W. dkk. (2008). Metode Pengembangan Perilaku dan Kemampuan Dasar Anak Usia Dini. Jakarta: Penerbit Universitas Terbuka.

Hernia, H. (2013). Kemampuan Mengenal Warna pada Anak Usia 4-5 Tahun di TK Segugus III Kecamatan Panjaitan Kabupaten Kulon Progo.Universitas Togyakarta. Yogyakarta: Skripsi tidak Dipublikasikan.

Hudi,K.A. (2012). Pengertian Kemampuan. Diakses dari [http://digilib.uinsby.ac.id/9227/5/bab\%202.pdf ]

Kasmiati. (2013). Meningkatkan Kemampuan Anak Mengenal Warna Melalui Eksperimen di Kelompok A TK Pertiwi Palu. Universitas Tadulako. Palu: Skripsi tidak Dipublikasikan

Kunandar. (2008). Penelitian Tindakan Kelas. Jagakarsa: Raja Grafindo Persada

Margono.S (2010:158). Metodologi Penelitian Pendidikan. Jakarta: PT Rineka Cipta

Meiliawati, E. (2015). Meningkatkan Kemampuan Mengenal Warna melalui Metode Eksperimen pada Anak Usia 3-4 Tahun di KB Melati Putih Jetis Bantul. Universitas Negeri Yogyakarta. Yogyakarta: Skripsi tidak Dipublikasikan.

Moedjiono \& Dimyati,M. (1991). Strategi Belajar Mengajar. Jakarta: Depdiknas.

Nugraha,A. (2005). Pengembangan Pembelajaran Sains pada Anak Usia Dini. Departemen Pendidikan Nasional.

Peraturan Menteri Pendidikan Nasional Nomor 58 Tahun 2009 Tentang Standar Pendidikan Anak Usia Dini.

Poerdarminta. (1996). Kamu s Umum Bahasa Indonesia. Pusat Bahasa Depatemen Pendidikan Dan Kebudayaan.

Poerdarminta. (2002). Kamus Bahasa Indonesia. Pusat Bahasa Departemen Pendidikan Nasional.

Roestiyah. (2001). Strategi Belajar Mengajar. Jakarta: Rineka Cipta.

Sanjaya. (2009). Strategi Pembelajaran. Jakarta: Kencana.

Sujiono, Y.N, dkk. (2005). Metode Pengembangan Kognitif. Jakarta: Universitas Terbuka

Sujiono, Y.N, dkk. (2011). Konsep Dasar PAUD. Jakarta: Indeks

Suyadi. (2010). Psikologi Belajar Pendidikan Anak Usia Dini. Yogyakarta Pedagogia.

Suyanto. (2005). Pembelajaran untuk Anak Taman Kanak-kanak. Departemen Pendidikan Nasional.

Suyanto. (2008). Dasar-dasar Pendidikan Anak Usia Dini. Yogyakarta: Hikayat Publising.

Syaiful Bahri Djamarah. (2005). Guru dan Anak Didik dalam Interaksi Edukatif. Jakarta: PT asdi Mahastya.

Undang-undang Nomor 20 Tahun 2003

Yuliani, N.S. dkk (2011). Metode Pengembangan Kognitif. Tangerang Selatan: Universitas Terbuka. 